\begin{tabular}{|c|c|}
\hline \multirow{3}{*}{ 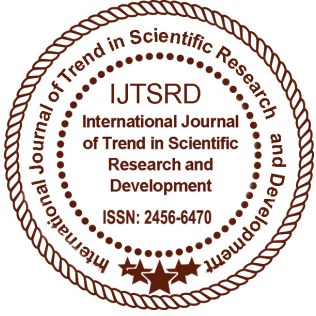 } & $\begin{array}{l}\text { International Journal of Trend in Scientific } \\
\text { Research and Development (IJTSRD) }\end{array}$ \\
\hline & International Open Access Journal \\
\hline & ISSN No: 2456 - 6470 | www.ijtsrd.com | Volume - 2 | Issue - 5 \\
\hline
\end{tabular}

\title{
The Influence of Compensation, Motivation and Work Environment on Performance with Job Satisfaction as Intervening Variable (A Study at Secretariate of Pasuruan Regency)
}

\author{
Satriya Yudianto ${ }^{1}$, Dwi Nita Aryani ${ }^{2}$ \\ ${ }^{1}$ PG Scholar, ${ }^{2}$ Lecturer \\ STIE Malangkuçeçwara, Malang, East Java, Indonesia
}

\begin{abstract}
The purposes of this research are to analyze the effect of compensation, motivation and work environment on performance; to analyze the influence of compensation, motivation and work environment on job satisfaction; to analyze the effect of job satisfaction on performance; and to analyze the influence of compensation, motivation and work environment on performance through job satisfaction as the intervening variable.
\end{abstract}

This research was conducted in the Secretariate of Pasuruan Regency with 135 respondents in all departments. The results of the research exhibited that there is a significant and positive influence between independent variable of compensation, motivation and work environment to dependent variable of performance; there is a significant and positive influence between compensation, motivation and work environment, and job satisfaction; there is a significant and positive influence between job satisfaction on performance; and there is a significant and positive indirect influence between independent variable of compensation, motivation and work environment on dependent variable of performance through job satisfaction variable as the intervening variable.

Keywords: Compensation, Motivation, Work Environment, Performance, Job Satisfaction

\section{INTRODUCTION}

Bureaucracy as an institution conducting public services at the central, provincial and district levels should have high performance in achieving organizational goals. As part of the existing bureaucracy in Indonesia in generally and in East Java Province in particularly, the Government of Pasuruan Regency with the Secretariate of Pasuruan Regency as one of the regional apparatus organization has a vision that is to realise the regional secretariate as an element of dynamic, proportional and professional administrative service in making local governmentpolicy. While the mission of Pasuruan Regency Secretariate is formulating a dynamic and applicative policies, effective and efficient administration of district administrations; and improving the quality of the dynamic, proportional and professional regional secretarial services. In the implementation of bureaucracy, Pasuruan Regency Secretariate has a task to assist the Regent in the formulation of policies and administrative coordination of the implementation of the tasks of the regional apparatus and administrative services, especially on the performance accountability system of government agencies.A review that has been done by Inspectorate of Pasuruan Regency on Performance Report of Government Institution, Pasuruan Regency Government achievedBB category in 2016 with score 74,18 based on the best achievement in 2015. But in 2017, the Pasuruan Regency Secretariateonly got a B category with score 66,83. However, since the beginning of 2017, the Pasuruan Regency has been giving Income Benefit Allowance for Regional Employees as ancompensation in order to stimulate the increasing of their performance. The declining of the score and how the benefit will affect the performance of Regional Employees attract to be studied by researchers. The need for high- 
performance bureaucracy is influenced by several factors hence the tasks and functions of an organization are also influenced by several variables.

Therefore, the authors are interested to examine the influence of compensation, motivation and work environment on performance with job satisfaction as intervening variable with the formulation of the problem as follows:

1. Is there any influence of compensation, motivation and work environment on performance?

2. Is there any influence of compensation, motivation and work environment on job satisfaction?

3. Is there any influence of job satisfaction on performance?

4. Is there influence of compensation, motivation and work environment to performance through job satisfaction as intervening variable?

The purposes of this research are to analyze the effect of compensation, motivation and work environment on performance; to analyze the influence of compensation, motivation and work environment on job satisfaction; to analyze the effect of job satisfaction on performance; and to analyze the influence of compensation, motivation and work environment on performance through job satisfaction as intervening variable.

\section{LITERATURE REVIEW}

According to Dessler [1], compensation has three components as follows:

1. Direct money payment (direct financial payment) in the form of salary, and intensive or bonus / commission.

2. 2.Indirect payment in the form of allowances and insurance.

3. Non-financial rewards such as flexible working hours and prestigious offices.

Hasibuan [2] asserted that the objectives of providing compensation include:

1. Cooperation Agreement

By providing compensation, formal ties between employers and employees are established. Employees must do their duties well, while employers must pay compensation according to the agreed agreement.
2. Job Satisfaction

With remuneration, employees will be able to meet their physical, social, and egoistic needs so as to obtain job satisfaction from their positions.

3. Effective Procurement

If the compensation program is set, the procurement of qualified employees for the company will be easier.

4. Motivation

If the remuneration is large enough, the manager will easily tomotivate his subordinates.

5. Employee Stability

With a compensation program based on fair and decent principles and complementary external consistency, employee stability is guaranteed because of relatively small turnover.

6. Discipline

With a large amount of remuneration, employee discipline is better. They will realize and obey the rules that apply.

7. Effect of Employee Organizations

With a good compensation program the influence of employee organization can be avoided and employees will concentrate on their work.

8. Government Influence

If the compensation program complies with applicable labor laws (such as minimum wage limits) then government intervention can be avoided.

McCormick in Mangkunegara [3] suggests that work motivation is defined as a condition that has an effect on generating, directing and maintaining work-related behaviors.

Maslow in Hariandja [4] stated that humans are motivated to satisfy a number of needs inherent in every human being who tends to be innate. He said that the five levels of need that reside within humans consist of:

1. Physiological, among others, the need for clothing, food, shelter and other physical needs.

2. Security, including the need for safety and protection against physical and emotional losses.

3. Social, including affection, a sense of belonging, good acceptance, friendship.

4. Awards, which include factors of self-respect such as self-esteem, autonomy, and achievement; as well as external self respect factors such as status, recognition and attention.

5. Self Actualization is an urge to become someone or according to his ambition which includes 
growth, achieving potential, and fulfilling one's needs.

According to Robbins [5] there are two well-known motivational theories that can be described as follows:

1. Herzberg's Two Factors Theory

This theory is based on interviews conducted by Herzberg. Research conducted by interviewing a number of people. Herzberg came to believe that two groups of factors that influence behavior are:

\section{A. Hygiene Factor}

This factor is related to the work context and the meaning of the work environment for individuals. The hygiene factors in question are working conditions, basic payments (salary), organizational policies, interpersonal relationships, and quality of supervision.

\section{B. Satisfier Factor}

The satisfying factor is related to the content of work and the definition of how a person enjoys or feels his work. The factor in question is achievement, recognition, responsibility and opportunity to develop. According to this theory the factors that encourage aspects of motivation are success, recognition, the nature of work that is the responsibility of a person, the opportunity to achieve progress, and growth. While the prominent hygiene factors are company policy, supervision, work conditions, wages and salaries, relationships with co-workers, personal life, relationships with subordinates, status, and security.

2. Three Types of Motivation by David McClelland

A. Need for Achievement (n-ACH)

The need for achievement is an encouragement to excel, achieving in relation to a set of standards, wrestling for success. This need in the Maslow hierarchy lies between the need for appreciation and the need for self-actualization. The characteristics of individuals who exhibit a high orientation include willingness to accept relatively high risks, the desire to get feedback about the results of their work, the desire to get problem solving responsibilities. n-ACH is the motivation for achievement, therefore employees will try to achieve their highest achievement, achieving these goals is realistic but challenging, and progress in work. Employees need to get feedback from their environment as a form of recognition of their achievements.

\section{B. Need for Power (n-pow)}

The need for power is the need to make other people behave in a way that those people without being forced will not behave in this way or a form of expression from the individual to control and influence others. This need in Maslow's theory lies between the need for appreciation and the need for self-actualization. McClelland stated that the need for power is closely related to the need to achieve a leadership position. n-pow is motivation for power. There is also motivation to improve personal status and prestige.

\section{Need to be affiliated or friendly (n-affil)}

The need for affiliation is the desire to relate to friendly and friendly individuals. Individuals reflect the desire to have a close, cooperative and friendly attitude with other parties. Individuals who have high affiliate needs generally succeed in work that requires high social interaction. McClelland said that most people have a combination of these characteristics, as a result will affect employee behavior in working or managing the organization.

In his theory McClelland argued that individuals have potential energy reserves, how this energy is released and developed depends on the strength or drive of the individual's motivation and the situation and opportunities available. This theory focuses on three needs, namely the need for achievement of needs, power, and affiliate needs. This motivation model is found in various organizational lines, both staff and managers. Some employees have characters that are a combination of these motivational models.

Work environment is everything that is around the job and that can affect employees in performing their duties, such as employee service, working conditions, employee relations within the company concerned [6]. Isyandi [7] said that the work environment is something that exists in the environment of workers who can affect themselves in carrying out tasks such as temperature, humidity, ventilation, lighting, noise, workplace cleanliness and the adequacy of work equipment.

According to Simanjuntak [8], the work environment can be interpreted as a whole tool faced, the surrounding environment in which a person works, his working method, as the influence of his work both as individuals and as a group.

According to Nitisemito in Nuraini [9] the work environment is everything that is around the employee and can affect in carrying out the tasks assigned to 
him for example by the presence of air conditioner, adequate lighting and so on.

Gomes [10] put forward the definition of performance as expressions such as output, efficiency and effectiveness often associated with productivity.

Foster and Seeker [11] state that performance is the result that someone achieves according to the size that applies to the job in question. Individual performance is the work of employees both in terms of quality and quantity based on predetermined work standards, while organizational performance is a combination of individual performance and group performance.

According Hariandja [12] explained that job satisfaction is the extent to which individuals feel positively or negatively various factors or dimensions of the tasks in the work.

According to Robbins [13], job satisfaction is a general attitude towards someone's work that shows the difference between the number of awards received by workers and the amount they believe they should receive.Job satisfaction is an affective or emotional response to various aspects or aspects of one's work so that job satisfaction is not a single concept. A person can be relatively satisfied with one aspect of work and not satisfied with one or more other aspects. Job Satisfaction is a (positive) attitude of workforce towards their work, which arises based on an assessment of the work situation. The assessment can be carried out on one of his jobs, the assessment is carried out as a sense of respect in achieving one of the important values in the work. Satisfied employees prefer the work situation to not like it. Feelings related to job satisfaction and job dissatisfaction tend to reflect the estimation of the workforce about current and past work experiences rather than expectations for the future. So it can be concluded that there are two important elements in job satisfaction, namely work values and basic needs. Job values are the goals to be achieved in carrying out work assignments. What is to be achieved is the values of work that are considered important by individuals. It was said further that work values must be appropriate or help fulfill basic needs.

According to Sari [14] in 2009, research on the Effect of Compensation and Climate Organization on Job Satisfaction resulted that the compensation proved to have a positive and significant impact on job satisfaction.
According to Siregar [15] in 2011, research on the Influence of Work Motivation, Individual Performance and Financial Compensation System on Job Satisfaction resulted that financial compensation proved to have a positive and significant effect on job satisfaction.

According to Sugiarti [16] in 2012, research on the Effect of Work Environment, Organizational Culture and Compensation on Job Satisfaction to Improve Employee Performance (research at the Faculty of Economics, University of 17th August 1945 Semarang) resulted that the compensation proved to have a positive and significant impact on job satisfaction, job satisfaction proven to mediate the effect of work environment on performance, job satisfaction proven mediate influence of compensation on performance.

According to Masrokah [17] in 2012, research on the Influence of Motivation, Job Satisfaction and Work Environment on the Performance of Official of Kelurahan Kedungsuko Subdistrict of Tulungagung Tulungagung Regency resulted that the work environment proved to have a positive and significant effect on performance, job satisfaction proved to have a positive and significant effect on the performance.

According to Husien and Hady [18] in 2012, research on the Effect of Work Environment and Individual Characteristics on Job Satisfaction of Hotel Melati Employees in Kecamatan Banjarmasin Tengah resulted that the work environment proved to have a positive and significant effect on the performance.

According to Soegihartono [19] in 2012, the Influence of Leadership and Job Satisfaction on Performance with Mediation Commitment (at PT Alam Kayu Sakti Semarang) resulted that employee performance is influenced by job satisfaction.

Based on the above problems, the hypotheses can beformulated as follows:

H1: There is influence of compensation, motivation and work environment on performance

$\mathrm{H} 2$ : There is influence of compensation, motivation and work environment to satisfaction work

H3: There is influence of job satisfaction on performance

H4: There is influence of compensation, motivation and work environment on performance through job satisfaction as intervening variable 


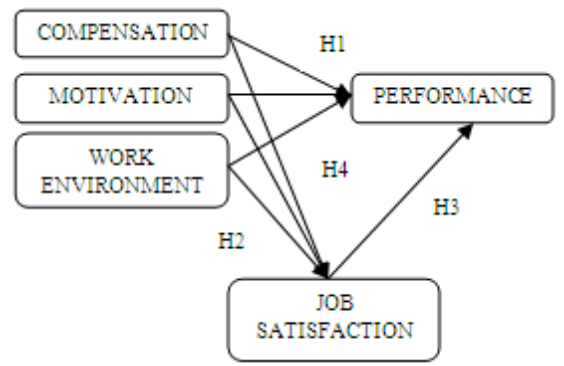

Figure 1 Conseptual Thinking Frame

\section{RESEARCH METHODOLOGY}

This research was conducted to test the hypotheses, with the intention of providing reinforcement of the hypothesis formulated with expectations supporting and reinforcing against the theory as the starting point of thinking. Explanatory Research will be employed in this study, due to the research aims to gather as much as information and as wide as possible on the object of research that has not been so widely known. This means that this research is useful to provide information in outline, or as a first step for more indepth research. Data can be obtained from the respondent's description and the required documents. In this research type and source of data used is primary data. Primary data is data directly given to the data collector. Primary data is usually obtained through the distribution of questionnaires to respondents. The population in this research is the employees of Pasuruan Regency Secretariate which amounts to 170 peoples. Based on the population data above, according to Isaac and Michael in Sugiyono [20] then the determination of the number of samples with a significance level of $1 \%$ is 135 peoples.

Scientific research should be supported by relevant, accurate, and reliable research materials therefore good data collection is required. In this research, data collection technique used is questionnaire.

The questions will be scored by using the Likert scale. Likert scale is used to measure attitudes, opinions, and perceptions of a person about a social phenomenonnamely compensation, motivation, work environment, performance and job satisfaction.

\section{RESEARCH RESULTS}

Table 1

\begin{tabular}{|c|c|c|c|c|c|}
\hline \multicolumn{7}{|c|}{ Coefficients $^{{ }^{2}}$} \\
\hline \multirow{2}{*}{ Model } & \multicolumn{1}{|c|}{ Unstd. Coef. } & Std. Coef & \multirow{2}{*}{ Sig. } \\
\cline { 2 - 5 } & B & Std. Error & Beta & & \\
\hline Constant) &, 679 &, 325 & & 2,086 &, 039 \\
\hline Compensation &, 287 &, 088 &, 200 & 3,282 &, 001 \\
\hline Motivation &, 335 &, 079 &, 374 & 4,230 &, 000 \\
\hline Work Environment &, 250 &, 065 &, 335 & 3,847 &, 000 \\
\hline \multicolumn{7}{|c|}{ a. Dependent Variable: Performance } \\
\hline
\end{tabular}

Source: SPSS ver 24.0 data processing

The result of data processing in table 1 shows that independent variables namely compensation, motivation and work environment significantly influence performance as dependent variable with Beta $20 \%, 37,4 \%$ and $33,5 \%$ respectively.With the significance of each independent variables less than
0.01 therefore $\mathrm{H} 1$ is accepted. This result is in line with Masrokah (2012) who mentioned that the work environment proved to have a positive and significant effect on performance.This result also consistent with Husien and Hady (2012) that work environment has a significant positive effect on performance.

Table 2

\begin{tabular}{|c|c|c|c|c|c|}
\hline \multicolumn{6}{|c|}{ Coefficients $^{\mathrm{a}}$} \\
\hline \multirow{2}{*}{ Model } & \multicolumn{2}{|c|}{ Unstd. Coef. } & \multirow{2}{*}{$\frac{\text { Std. Coef }}{\text { Beta }}$} & \multirow{2}{*}{$\mathbf{t}$} & \multirow{2}{*}{ Sig. } \\
\hline & B & Std. Error & & & \\
\hline (Constant) &, 352 &, 179 & & 1,971 & ,051 \\
\hline Compensation & ,306 & 058 & ,361 & 5,270 &, 000 \\
\hline Motivation & ,380 & 087 & ,358 & 4,368 & ,000 \\
\hline Work Environment & 202 & ,063 & ,228 & 3,188 & ,002 \\
\hline a. Dep & dent & ariable: $\mathrm{J}$ & Satisfact & & \\
\hline
\end{tabular}


The result of data processing in table 2 exhibited that compensation, motivation and work environment influence job satisfaction significantly with Beta $36,1 \%, 35,8 \%$ and $22,8 \%$ respectively. With the significance of each independent variables less than 0.01.Hence $\mathrm{H} 2$ is accepted.This result is in line with Sari (2009) who found that compensation has a positive and significant impact on job satisfaction.

Table 3

\begin{tabular}{|c|c|c|c|c|c|}
\hline \multicolumn{7}{|c|}{ Coefficients $^{\text {a }}$ Model } & \multicolumn{2}{|c|}{ Unst. Coef. } & Std. Coef & \multirow{2}{*}{ t } & \multirow{2}{*}{ Sig. } \\
\cline { 2 - 4 } & B & Std. Error & Beta & & \\
\hline (Constant) & 2,125 &, 210 & & 10,099 &, 000 \\
\hline Job_Satisfaction &, 499 &, 059 &, 592 & 8,473 &, 000 \\
\hline
\end{tabular}

a. Dependent Variable: Performance

Source : SPSS ver 24.0 data processing

Table 3 explains that job satisfaction significantly therefore $\mathrm{H} 3$ is accepted.This result is in line with influence of performance with beta 59,2\%. With the Soegihartono (2012) who asserted that employee significance of independent variable less than 0.01, performance is influenced by job satisfaction.

Table 4 Standardized Direct Effects (Group number 1 - Default model)

\begin{tabular}{|c|c|c|c|c|}
\hline & Work_Environment & Motivation & Compensation & Job_Satisfaction \\
\hline Job_Satisfaction &, 271 &, 332 &, 110 &, 000 \\
\hline Performance & 233 &, 289 &, 026 &, 375 \\
\hline
\end{tabular}

Source: : AMOS ver 24.0 data processing

Variables of compensation, motivation and work environment affect performance with beta respectively $2,6 \%$, $28,9 \%$ and $23,3 \%$ as shown in table 4 , while direct influence equal to $37,5 \%$ come from variable job satisfaction.

Table 5 Standardized Indirect Effects (Group number 1 - Default model)

\begin{tabular}{|c|c|c|c|c|}
\hline & Work_Environment & Motivation & Compensation & Job_Satisfaction \\
\hline Job_Satisfaction &, 000 & 24,00064 & $0 \quad, 000$ &, 000 \\
\hline Performance &, 352 &, 375 &, 241 &, 000 \\
\hline
\end{tabular}

Source : AMOS ver 24.0 data processing

Meanwhile, indirect influence of independent variables of compensation, motivation and work environment on performance dependent variable respectively are $24,1 \%, 37,5 \%$ and $35,2 \%$.Along with that $\mathrm{H} 4$ is accepted.This result is in line with Sugiarti (2012) that job satisfaction proven to mediate the effect of work environment on performance and also job satisfaction proven to mediate influence of compensation on performance.
The value of adjusted $\mathrm{R}$ square of the research model (table 6) is 0,728 and closer to 1 than 0 . This means that the capability of independent variables namely compensation, motivation and work environment in describing variation on dependent variable performance is getting higher i.e $72.8 \%$, and the rest is explained by other variables.

Table 6

\begin{tabular}{|c|c|c|c|c|}
\hline \multicolumn{5}{|c|}{ Model Summary } \\
\hline Model & $\mathrm{R}$ & R Square & Adjusted R Square & Std. Error of the Estimate \\
\hline 1 &, $857^{\mathrm{a}}$ &, 734 &, 728 &, 30960 \\
\hline \multicolumn{5}{|c|}{ a. Predictors: (Constant), Work Environment, Compensation, Motivation } \\
\hline
\end{tabular}

Source : SPSS ver 24.0 data processing 
This is plausible due to since the beginning of 2017, any compensation has been given in the form of Income Improvement Allowances for Regional Employees in the Pasuruan Regency Government in accordance with Pasuruan Regent Regulation No. 38 of 2016. This shows that employees in Pasuruan Regency Government have received compensation. While in terms of motivation, executive positions for employees in the Government of Pasuruan Regency have been regulated in the Regulation of the Minister of Administrative Reform and Bureaucratic Reform No. 25 of 2016 which is updated with the Regulation of the Minister of Administrative Reform and Bureaucratic Reform No. 18 of 2017 about Nomenclature of Executive Positions in the Environment Government Agencies. Then there is also a Government Regulation Number 11 of 2017 about Management of Civil Servants which regulates competency and career development for civil servants including in the Pasuruan Regency Government.With the enactment of a new Government Regulation that regulates the salaries of civil servants where the value of the new salary is greater than the previous salary, it certainly also motivates civil servants in the Pasuruan Regency Government to improve their performance.

Moreover, this also supported by work environment of employees in Pasuruan Regency Government which includes work facilities and infrastructures that have been regulated in the Minister of Internal Affairs Regulation No. 7 of 2006 which has been updated with the Minister of Internal Affairs Regulation No. 11 of 2007 concerning the standardization of work facilities and infrastructures of the regional government in regulating the room offices, office supplies, official homes and official vehicles. So the work environment and work facilities for civil servants have been arranged in such a way as to provide the best service to the public without neglecting the convenience of working for the civil servants themselves.

Performance employees are measured by performance accountability system of government agencies in accordance with the Minister of State Apparatus and Bureaucratic Reform Regulation No. 53 of 2014 concerning Technical Guidelines for Performance Agreements, Performance Reporting and Review Procedures for Government Institution Performance Reports. In addition, performance planning, performance measurement, performance analysis and performance evaluation, all of which are summarized in performance reporting. From the performance report can be seen an increase or decrease in performance that has been achieved in the past year. This shows that the performance of civil servants can be measured by certain standards set by the ministry concerned.

The job satisfaction of Pasuruan Regency Government employees is reflected in the new payroll system plan for civil servants through a new Government Regulation on salary. The existing position is in the process of submitting a class assignment to the Ministry of State Apparatus and Bureaucratic Reform where each position has the value of each position and the basis of the compensation will refer to the position class or level so that the provision of reward and punishment runs fairly. Then also the current work environment has been regulated by the Government of the Republic of Indonesia through the Ministry of Internal Affairs therefore public services can be maximized without sacrificing employee work comfort. In the future career promotion will be more transparent and fair with the implementation of auction positions and the existence of competency standards to achieve a position there is no filling in positions based on likes or dislikes. In Pasuruan Regency the work atmosphere is very conducive because it prioritizes local wisdom that is religious and polite as a hallmark of Islamic boarding schools.

Based on the foregoing, it is evident that the provision of compensation, motivation and work environment has a linear and positive effect on employee performance in the Pasuruan Regency Government. Furthermore, the effect of providing compensation, motivation and work environment to employees in the Pasuruan Regency Government towards performance is getting stronger with job satisfaction as an intervening variable.

\section{CONCLUSIONS}

This research conclude that :

1. There is a significant and positive influence between the independent variables namely compensation, motivation and work environment on performance as dependent variable with beta $20 \%, 37.4 \%$ and $33.5 \%$.

2. There is a significant and positive influence between eompensation, motivation and work environment and job satisfaction with $36.1 \%$, $35.8 \%$ and $22.8 \%$. 
3. There is a significant and positive influence between job satisfaction and performance equal to $59.2 \%$.

4. There is a significant indirect and positive influence between compensation, motivation and work environment on performance through job satisfaction as intervening variable respectively by $24.1 \%, 37.5 \%$ dan 35.2\%.A direct influence between compensation, motivation and work environment on performance respectively by $2.6 \%, 28.9 \%$ and $23.3 \%$.

\section{REFFERENCES}

1. Dessler, Garry, "Human Resource Management 10th Edition", Jakarta : PT. Indeks, 2009

2. Hasibuan , Malayu S. P, "Human Resource Management", Jakarta : Bumi Aksara, 2002

3. Mangkunegara, A A. Anwar Prabu, "Human Resource Management", Bandung : PT. Remaja Rosda Karya, 2002

4. Hariandja, Marihot Tua Efendi, "Human Resource Management", Jakarta : Grasindo, 2002

5. Robbins, Stephen P, "Organizational Behaviour : Concept, Controversy, Application, Volume 1, $8^{\text {th }}$ Edition, Jakarta : Prenhallindo, 2001

6. Surodilogo, Leonardus Bintoro, "Analysis of the Effect of Work Environment and Work Motivation on Employee Job Satisfaction of PT. Sumber Sehat Semarang", Unpublished undergraduate thesis, Semarang: Faculty of Economy Diponegoro University, 2010

7. Isyandi, B, "Human Resource Management in Global Perspective", Pekanbaru : Unri Press, 2004

8. Simanjuntak, Payaman J, "Work Productivity Understanding and Scope", Jakarta : Prisma, 2003

9. Nuraini, T, "Human Resource Management", Pekanbaru :Yayasan Aini Syam, 2013

10. Gomes, Faustino Cardosa, "Human Resource Management”, Yogyakarta : Andi Offset, 2005
11. Foster, Bill dan Karen R. Seeker, "Coaching To Improve Employee Performance", Jakarta : PT.Toko Gunung Agung Tbk, 2001

12. Hariandja, Marihot Tua Efendi, "Human Resource Management", Jakarta : PT. Glamedia Widiasarana, 2005

13. Robbins, Stephen P, "Organizational Behaviour", Jakarta : PT. Indeks, 2003

14. Sari, Elviera, "Effect of Organizational Compensation and Climate on Job Satisfaction", Administrative and Organizational Science Journal Volume 16 Num. 1 p. 18-24, 2009

15. Siregar, Edi, "Effect of Work Motivation, Individual Performance and Financial Compensation System on Job Satisfaction", Educational Journal Penabur, 16, p:81-93, 2011

16. Sugiarti, Gita, "The Influence ofthe Work Environment, Organizational Culture and Compensation for Job Satisfaction to Improve Employee Performance (Study at the Faculty of Economics, University of August 17, 1945 Semarang)", Scientific Journal Serat Acitya Untag Semarang, Volume 1 Num. 2, p : 73-83, 2012

17. Masrokah, "The Effect of Motivation, Job Satisfaction and Work Environment on the Employee Performance of the Kedungsuko Village Office, Tulungagung District, Tulungagung Regency", Otonomy Journal Vol. 12 Num.2. p : 12-25, 2012

18. Husien, Nirza Marzuki, \& Hady, Andrian, "The Effect of Work Environment and Individual Characteristics on Job Satisfaction of Budget Hotel Employees in Central Banjarmasin District", Management and Accounting Journal Volume 13 Num. 1, p : 35-44, 2012

19. Soegihartono, A., "The Effect of Leadership and Job Satisfaction on Performance by Commitment Mediation (at PT. Alam Kayu Sakti Semarang)", Economic Partner and Business Management Journal, Vol. 3 Num.1, 2012

20. Sugiyono, "Qualitative and Quantitative and R\&D Research Method”, Bandung : Alfabeta, 2012 